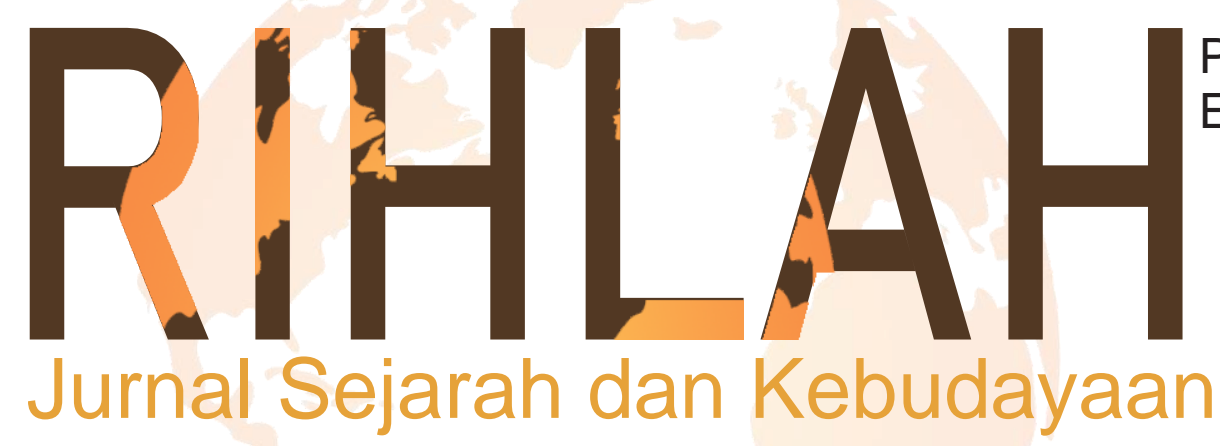

P-ISSN: 2339-0921

E-ISSN: 2580-5762

Pengaruh Bugis di Tanah Melayu dalam Perspektif Sejarah Sosial Politik Saepuddin

Akulturasi Budaya: Adat Pernikahan di Kelurahan Cikoro Kecamatan Tompobulu Kabupaten Gowa St. Hajar, M. Dahlan M, Syamzan Syukur

Corry Van Stenus, Perempuan dalam Perjuangan Abdul Qahhar Mudzakkar (1950-1965) Nurul Azizah

Sejarah dan Penyebaran Islam di Asia dan Afrika Herman Wicaksono

Sarekat Islam Penggagas Nasionalisme di Indonesia Soraya Rasyid, Annisa Tamara

Bergerak dengan Dua Sayap: Fenomena Gerakan Dakwah dan Politik Hizbut Tahrir di Indonesia Pasca Reformasi Aksa 


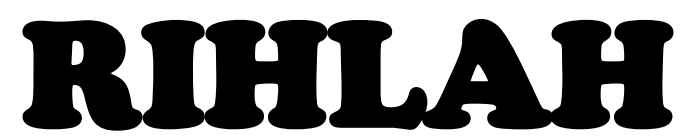

Jurnal Sejarah dan Kebudayaan

\begin{tabular}{|c|c|}
\hline Editor in Chief & Dr. Rahmat, M.Pd. \\
\hline Managing Editor & Mastanning, S.Hum, M.Hum. \\
\hline Editorial Board & $\begin{array}{l}\text { : Nur Ahsan Syukur, S.Ag, M.Si. } \\
\text { : Chaerul Munzir, S.Hum, M.Hum. } \\
\text { : Lydia Megawati, S.Hum, M.Hum. } \\
\text { : Muhammad Husni, S.Hum, M.Hum. } \\
\text { : Zaenal Abidin, S.S., M.H.I. } \\
\text { : Chusnul Chatimah Asmad, S.IP, M.M. } \\
\text { : Muhammad Arif, S.Hum, M.Hum. } \\
\text { : Nurhidayat, S.Hum, M.Hum. }\end{array}$ \\
\hline Desain Grafis & Nur Arifin, S.IP. \\
\hline Secretariat & Safaruddin, S.Hum. \\
\hline Reviewers & $\begin{array}{l}\text { : Prof. Dr. H. Abd. Rahim Yunus, M.A. } \\
\text { : Prof. Dr. H. Ahmad M. Sewang, M.Ag. } \\
\text { : Dr. Hj Syamzan Syukur, M.Ag. } \\
\text { : Dr. Nasruddin Ibrahim. } \\
\text { : Dr. Abd. Rahman Hamid. } \\
\text { : St. Junaeda, M.Hum. } \\
\text { : Dr. Rahmawati, MA. } \\
\text { : Dr. Nurhayati Syairuddin, M.Hum }\end{array}$ \\
\hline
\end{tabular}

Alamat Redaksi dan Tata Usaha : Jurusan Sejarah dan Kebudayaan Islam Fakultas Adab dan Humaniora UIN Alauddin Makassar, Jln. Sultan Alauddin No. 36 Samata Gowa Tlp. 0411-841879 Fax.0411-822140 (Kampus II) E.Mail. rihlah@uin-alauddin.ac.id

Jurnal Rihlah terbit dua kali dalam setahun, bulan Juni dan bulan Desember berisi kajian tentang Sejarah dan Kebudayaan, baik dari hasil penelitian maupun tulisan ilmiah lainnya.

Penyunting menerima tulisan yang belum pernah diterbitkan oleh media cetak lain. Naskah diketik spasi $1 \mathrm{~cm}$ pada kertas berukuran A4 dengan tulisan berkisar 12-23 halaman. Naskah yang masuk dievaluasi oleh Dewan Penyunting. Penyunting dapat melakukan perubahan pada tulisan yang dimuat untuk keseraganan format, tanpa mengubah maksud dan konten tulisan. 
Saepuddin $01-17$

Pengaruh Bugis di Tanah Melayu dalam Perspektif Sejarah Sosial Politik

St. Hajar, M. Dahlan M, Syamzan Syukur

Akulturasi Budaya: Adat Pernikahan di

Kelurahan Cikoro Kecamatan Tompobulu

Kabupaten Gowa

Nurul Azizah.

Corry Van Stenus, Perempuan dalam Perjuangan

Abdul Qahhar Mudzakkar (1950-1965)

Herman Wicaksono.

Sejarah dan Penyebaran Islam di Asia dan Afrika

Soraya Rasyid, Annisa Tamara

$66-84$

Sarekat Islam Penggagas Nasionalisme di Indonesia

Aksa

Bergerak dengan Dua Sayap: Fenomena Gerakan Dakwah

dan Politik Hizbut Tahrir di Indonesia Pasca Reformasi 


\title{
Akulturasi Budaya: Adat Pernikahan di Kelurahan Cikoro Kecamatan Tompobulu Kabupaten Gowa
}

\author{
St. Hajar M. Dahlan M, Syamzan Syukur \\ Universitas Islam Negeri Alauddin Makassar \\ hhajra182@gmail.com
}

\begin{abstract}
This research will answer a number of questions, namely: 1) How is the procession of the wedding customs inCikoro Village, Tompobulu District, Gowa Regency?; 2) What are the values of Islamic culture of the wedding customs inCikoro Village, Tompobulu District, Gowa Regency? 3) How is the process of Islamic culture acculturation of the wedding customs in Cikoro Village, Tompobulu District, Gowa Regency? A wedding involves not only the bride and groom but also all extended families, neighbors and the societies. The wedding customs in the Cikoro Village consist of two stages, namely: the stage before marriage and the stage after marriage. The custom of marriage in the Cikoro Village is very unique compared to the custom of marriage in other regions, in the Cikoro Village the wedding party takes precedence over the marriage contract. The acculturation has further strengthened the custom of marriage in Cikoro Village with Islamic cultural values
\end{abstract}

Keyboard: acculturation, customs, marriage.

Abstrak

Penelitian ini akan menjawab pertanyaan 1. Bagaimana prosesi dalam adat pernikahan di Kelurahan Cikoro Kecamatan Tompobulu Kabupaten Gowa?, 2. Apa saja nilai-nilai budaya Islam dalam adat pernikahan di Kelurahan Cikoro Kecamatan Tompobulu Kabupaten Gowa?, 3. Bagaimana proses akultuasi budaya Islam dan budaya lokal dalam adat pernikahan di Kelurahan Cikoro Kecamatan Tompobulu Kabupaten Gowa? Pernikahan di Kelurahan Cikoro disebut dengan istilah pa'buntingan, tidak hanya melibatkan keluarga inti tapi juga masyarakat luas dan terdiri dari dua tahap, yakni: tahap sebelum pernikahan dan tahap setelah pernikahan. Adat pernikahan di Kelurahan Cikoro sangat unik jika dibandingkan dengan adat pernikahan di daerah lain, di Kelurahan Cikoro pesta pernikahan didahulukan daripada akad nikah. Terjadinya akulturasi semakin memperkokoh adat pernikahan di Kelurahan Cikoro dengan nilai budaya Islam

Kata kunci: akulturasi, adat, pernikahan.

\section{Pendahuluan}

Setiap daerah memiliki adat yang berbeda dengan daerah lain, tak terkecuali di Kelurahan Cikoro, sebelum masuknya Islam masyarakat di Kelurahan Cikoro 
telah memegang budaya siri. Siri adalah rasa malu, rasa kehormatan, harga diri oleh kerena itu harus dijaga, begitu tingginya nilai siri karena nipakasiri (dipermalukan) nyawa taruhannya.

Adat pernikahan di Kelurahan Cikoro mengandung banyak nilai budaya yang secara turun-temurun diwariskan oleh nenek moyang. Dalam pelaksanaan adat pernikahan di Kelurahan Cikoro mengundang banyak masyarakat luas untuk ikut serta dalam merayakan kebahagiaan dengan disatukannya dua insan dalam ikatan yang sakral dan suci.

Menurut Soemiyati ${ }^{1}$ pernikahan adalah ikatan suci antara laki-laki dan perempuan, yang memerlukan kasih sayang, tanggungjawab, pengorbanan dan komitmen.

Dalam Undang-undang Republik Indonesia Nomor 1 Tahun 1974², pernikahan adalah ikatan lahir batin antara laki-laki dan perempuan dengan harapan membangun rumah tangga yang harmonis dan bahagia berdasarkan Ketuhanan Yang Mahaesa.

...Allah berfirman dalam QS. al-Ruum/30: 21.

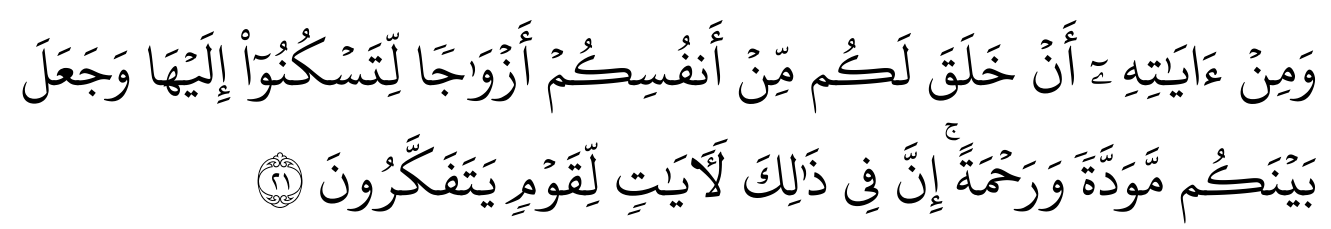

Terjemahnya:

Dan di antara tanda kekuasaan Allah, Dia menciptakan untukmu isteri-isteri dari jenismu sendiri, agar kamu cenderung dan merasa tenteram kepada-Nya, dan dijadikan-Nya di antaramu rasa kasih sayang. Sesungguhnya pada demikian itu, terdapat tanda-tanda bagi kaum yang berpikir. ${ }^{3}$

Pernikahan adalah jalan untuk membangun keluarga antara laki-laki dan perempuan menjadi hubungan yang tenteram karena terciptanya rasa kasih sayang di antara keduanya.Dalam Islam pernikahan sangat sederhana, namun budaya setiap kelompok masyarakat memberikan respon yang berbeda-beda sebagai lambang dari suatu daerah.

Penelitian ini akan mendeskripsikan dan menganalisa adat pernikahan di Kelurahan Cikoro yang unik karena mendahulukan pesta pernikahan daripada akad nikah, padahal akad nikah adalah puncak dari rangkaian adat pernikahan, tidak akan ada pesta pernikahan tanpa akad nikah. Namun menurut pandangan peneliti dalam konteks ini tidak bertentangan dengan ajaran agama Islam.

\footnotetext{
${ }^{1}$ Soemiyati, Hukum Perkawinan Islam dan Undang-undang Perkawinan (Cet. IV; Yogyakarta: Liberty, 1999), h. 30. 2012), h. 2 .

${ }^{2}$ Undang-undang RI No. 1 Tahun 1974 tentang pernikahan (Bandung: Citra Umbara, 406.

${ }^{3}$ Departemen Agama RI, Alqur'an dan Terjemahnya (Depok: Cahaya Qur'an, 2008), h.
} 
Disamping itu pula terkandung banyak nilai budaya Islam yang harus dilestarikan dari generasi ke genarasi. Proses akulturasi telah membawa warna yang baru dalam adat pernikahan di Kelurahan Cikoro.

Berikut ini akan diuraikan bagaimana adat pernikahan di Kelurahan Cikoro Kecamatan Tompobulu Kabupaten Gowa. Mulai dari tahap awal sampai tahap akhir dari rangkaian pernikahan akan dibahas dalam artikel ini.

\section{Prosesi Adat Pernikahan di Kelurahan Cikoro Kecamatan Tompobulu Kabupaten Gowa}

Adat bagi masyarakat di Kelurahan Cikoro sangat berbeda dengan daerah lain, ini bisa dilihat dalam budaya lokal setempat yang masih dipertahankan sampai sekarang. Kemajuan pendidikan dan munculnya budaya-budaya baru bagi masyarakat di Kelurahan Cikoro yang lebih memudahkan seperti mendahulukan akad nikah kemudian menggelar pesta pernikahan yang waktunya lebih singkat dan lebih gampang tidak serta merta mempengaruhi budaya lokal setempat dalam proses pernikahan, seperti halnya mendahulukan pesta daripada akad nikah. Budaya ini masih dipertahankan sampai sekarang, ini bisa dilihat dalam proses pernikahan di Kelurahan Cikoro.

1. Tahap Pra Nikah

a) Mencari Informasi (Akkuta'nang)

Mencari informasi tentang gadis yang ingin dilamar adalah tahap paling utama dilakukan dalam adat pernikahan di Kelurahan Cikoro, tujuannya bukan sekedar untuk mengetahui apakah gadis tersebut sudah ada yang meminangnya atau belum, tetapi sebagai bentuk penghargaan kepada orang tua perempuan. Meskipun calon pengantin saling suka dan diketahui oleh kedua belah pihak, akkuta'kuta'nag tetap dilakukan. Dalam tahap ini salah seorang pihak laki-laki yang disebut utusan tak resmi, mancari tahu tentang gadis yang ingin dilamar melalui orang tuanya. Utusan tak resmi tersebut datang ke rumah orang tua sigadis dengan membawa sebungkus rokok sebagai pembuka mulut. Orang tua sigadis akan memberi keputusan kepada utusan tak resmi setelah tiga hari kedatangannya akkuta'kuta'nang.

b) Melamar (mae boya)

Setelah ada kepastian dari pihak perempuan tahap selanjutnya adalah melamar, dalam proses lamaran masihterlihat sederhana dan hanya dihadiri kurang lebih 10 orang laki-laki yang cukup disegangi dari pihak laki-laki. Tahap ini akan berbicara mengenai uang panai dan sunrang. Menurut M. Amir ${ }^{4}$, uang panai adalah uang yang harus dipenuhi pihak laki-laki yang diberikan kepada pihak perempuan sebagai biaya dalam proses pernikahan. Begitu pula menurut $\mathrm{H}$. Mahmuddin ${ }^{5}$, uang panai adalah biaya yang diterima pihak perempuan untuk biaya pernikahan. Sedangkan sunrang adalah pemberian calon pengantin laki-laki kepada calon isterinya.

${ }^{4}$ M. Amir, Imam Lingkungan Parangkeke "Hasil Wawancara", 08 Desember 2019.

${ }^{5}$ H. Mahmuddin, Kepala Lingkungan Parangkeke "Hasil Wawancara", 06 Desember 2019. 
Berbicara mengenai lamaran waktunya agak lama karena sudah memasuki pertanyaan inti, yaitu tentang uang panai dan sunrang,berbicara mengenai uang panai bukan perkara yang muda dan sering menimbulkan debat panjang. Oleh karena itu orang yang datang melamar adalah orang yang dipercayai oleh pihak laki-laki bisa menjaga ketersinggungan di antara kedua belah pihak.

Setelah ada kesepakatan di antara kedua belah pihak, maka pihak laki-laki akan meminta waktu untuk datang kembali membawa uang panai' yang sudah disepakati.

c) Menentukan hari pernikahan(pattantu allo pa'buntingan)

Penentuan hari pernikahan dihadiri lebih banyak dari sebelumnya, yang datang pattantu allo laki-laki dan perempuan yang merupakan keluarga inti dari pihak laki-laki. Penentuan hari pernikahan berpatokan dengan kesibukan masingmasing pihak, di Kelurahan Cikoro tidak begitu mempersoalkan tentang hari yang dianggap sakral atau allo baji (hari baik).

d) Membawa uang panai'

Dihari yang telah disepakati datanglah pihak laki-laki membawa uang panai'(panai balanja), acara ini cukup meriah karena sudah mengundang keluarga besar dan tetangga. Pada umumnya membawa uang panai digelar di siang atau sore hari, bukan hanya uang saja yang dibawa oleh pihak laki-laki tetapi berbagai macam kue seperti dodol, bannang-bannang,baje, bolu dan lain-lain yang disebut erangerang.erang-erang ini akan dibagikan oleh orang tua calon pengantin perempuan kepada tetangga-tetangganya. Menurut Ustadz Amir,

Uang panai' adalah uang yang diberikan kepada pihak perempuan untuk biaya pernikahan ${ }^{6}$. Jumlah uang tersebut sudah disepakati dalam proses lamaran, uang panai ini sebagai lambang kehormatan wanita yang dilamar, besar kecilnya tergantung pengalaman kedua belah pihak saat menyelenggarakan pernikahan sebelumnya, dan terkadang pula dilihat dari strata sosial wanita tersebut.

e) Baung landang (tambahan rumah)

Setelah panai balanja selesai, itu menandakan tidak lama lagi pesta dan akad nikah akan segera diselenggarakan, maka kedua belah pihak akan disibukkan dengan persiapan menyambut acara tersebut seperti mengundang keluarga inti dan tetangga (khusus laki-laki) untuk membangun tambahan rumah sebagai tempat untuk memasak di samping kiri atau kanan rumah.

Tambahan rumah yang dibangun hanya sementara dan akan dibongkar kembali setelah acara selesai, dan membongkarnya harus pula mengundang atau memanggil tetangga. Bahan utama dari baung landang ini adalah: bambu, paku, terpal dan kayu.

f) Banngi Cidong-cidong (malam pesta)

Malam pesta adalah malam yang paling ditunggu-tunggu oleh keluarga besar dan masyarakat. ${ }^{7}$ Karena pada malam ini kedekatan antara keluarga dan bukan

${ }^{6}$ M. Amir, Imam Lingkungan Parangkeke "Hasil Wawancara”, 08 Desember 2019.

${ }^{7}$ Nurlia, tokoh masyarakat, “Hasil Wawancara”, 11 Desember 2019. 
keluarga akan terlihat sangat berkesan. Menurut Dg. $\mathrm{Hapa}^{8}$ malam pesta atau banngi cidong-cidong adalah malam berkumpulnya keluarga besar, jauh, dekat, tua, muda, laki-laki maupun perempuan.

g) Borong-borong (hari pernikahan)

Pesta atau hari pernikahan digelar sebelum akad nikah. Oleh karena itu pengantin perempuan duduk dipelaminan sendiri, sementara pengantin laki-laki hanya disibukkan dengan menyambut tamu undangan. Namun terkadang di Kelurahan Cikoro pengantin perempuan tidak ingin duduk dipelaminan pada hari pestanya dan lebih memilih menyambut tamu undangan.

Tamu undangan yang datang ke pesta pernikahan kedua belah pihak biasanya remaja laki-laki dan orang tua membawa uang passolo, ibu-ibu membawa beras, gular pasir dan sabun cuci dalam sebuah wadah yang berisikan 10-12 liter dan remaja perempuan membawa kado, seperti seprei, sarung, atau kado lainnya. Kado bawaan remaja perempuan ini khusus untuk pengantin perempuan. Sementara untuk pengantin laki-laki identik dengan uang, beras, gula pasir atau sabun cuci.

Uang passolo umumnya mencapai 20-30 juta, kado berupa sarung dan seprei sampai puluhan, beras 500 liter-1 ton. Semua passolo dicatat dan nantinya akan diganti saat melakukan hajatan.

h) Pasimorong

Mengantar calon pengantin laki-laki ke rumah calon pengantin perempuan untuk melangsungkan akad nikah atau dalam istilah di Kelurahan Cikoro pasimorong.Pasimorong ini orang tua pengantin laki-laki tidak boleh ikut, dan hanya ditemani oleh keluarga dan tetangganya, pasimorong berlangsung di sore hari dan akad nikah pada malam hari sekitar pukul 20:00.

Menurut Dg. Ngasi ${ }^{9}$ akad nikah dilakukan pada malam hari agar suasana menjadi tenang karena dalam proses akad nikah harus dengan suasana yang tenang, dan malam hari adalah waktu yang paling tenang dibandingkan dengan waktu lain. Sedangkan menurut Nurlailatul Qadri ${ }^{10}$ akad nikah digelar pada malam hari alasannya agar pihak perempuan tidak direpotkan dengan tamu undangan dan pengantar pengantin laki-laki, agar ada jarak tamu undangan dan pengantar pengantin maka dari itu akad nikah harus di malam hari.

Dalam pasimorong ini ada banyak bawaan pihak laki-laki yang disebut erangerang yang mengandung banyak makna, menurut $\mathrm{H}$. Mahmuddin ${ }^{11}$ makna dari erang-erang itu, seperti:

1. Kelapa muda dan gula merah dengan harapan agar kehidupan kedua mempelai selalu nyaman dengan suasana yang selalu bersatu. Dilihat

${ }^{8}$ Dg. Hapa, tokoh masyarakat, "Hasil Wawancara”, 11 Desember2019.

${ }^{9}$ Dg. Ngasi, tokoh masyarakat, "Hasil Wawancara”, 06 Desember 2019.

${ }^{10}$ Nurlailatul Qadri, tokoh masyarakat, "Hasil Wawancara”, 05 Desember 2019.

${ }^{11}$ H. Mahmuddin, Kepala Lingkungan Parangkeke, "Hasil Wawancara" 06 Desember 2019. 
makna dari kelapa muda dan gula merah jika disatukan rasanya sangat enak.

2. Daun siri, harapannya agar keduanya selalu menjaga harga diri dan kehormatannya.

3. Pisang ambon, di Kelurahan Cikoro disebut dengan istilah unti la'bu (pisang panjang), maknanya agar kehidupan pasangan suami istri berumur panjang dan hanya maut yang bisa memisahkan.

4. Songkolo, agar kehidupan keduanya selalu menyatu dan sulit dipisahkan, jika dilihat dari songkolo ini sangat mudah menyatu.

5. Kue, kue beraneka macam seperti dodol (kue khas), baje, bannangbannang, kue bolu, lapis dan lain-lain. Tujuan dari kue ini hanya untuk dibagikan oleh orang tua pengantin perempuan kepada keluarga dan tetangganya.

Erang-erang dalam prosesi adat pernikahan di Kelurahan Cikoro hampir ada disetiap prosesinya, dan setiap ada erang-erang harus dibagi kepada keluarga dan tetangga sebagai salah satu tanda terima kasih.

i) Akad nikah.

Puncak dari rangkaian acara adalah akad nikah, akad nikah adalah acara yang paling ditunggu kedua belah pihak. Masyarakat di Kelurahan Cikoro $100 \%$ beragama Islam,dalam prosesi ijab qabul dilakukan dengan cara islami. Calon mempelai laki-laki terlebih dahulu dites mengaji oleh iman atau ustads, kemudian penyerahan sunrang kepada, jika sunrangnya tanah maka yang ditunjukkan bukti atau surat yang didalamnya disaksikan oleh lurah atau desa setempat, membaca kedua kalimat syahadat lalu akad nikah dimulai.

Penghulu: Kupa'nikkako siagan anak bainena deng(.......)niarenga(.........) nusunrang sisapa' butta nasaba Allah ta'ala. Maknanya: Saya nikahkan engkau dengan anak perempuan dari (......) atas nama (............) dengan mahar 1 hektar tanah karena Allah swt.

Mempelai laki-laki: Kutarimai nikkana anak bainena deng (.....) niarenga (.......) kusunrang sisapa butta karena Allah ta'ala. ${ }^{12}$ Maknanya: Saya terima nikahnya anak perempuan dari(.......) atas nama (......)dengan mas kawin satu hektar tanah karena Allah swt.

Setelah akad nikah, pengantin laki-laki akan dituntun oleh salah-satu anggota keluarganya untuk menemui isterinya di dalam kamar. Pertemuan pertama setelah resmi jadi suami isteri disebut padongko nikkah.

2. Tahap Setelah Menikah

a) Padongko Nikka atau pabattu nikka

Prosesi ini,pengantin laki-laki memasuki kamar isterinya diantar oleh salah seorang anggota keluarganya, sebelum masuk kamar akan terjadi dialog antara pengantar pengantin laki-laki dan penjaga kamar perempuan, kurang lebih seperti berikut:

\footnotetext{
${ }^{12}$ M. Amir, Imam Lingkungan, “Hasil Wawancara”, 08 Desember 2019.
} 
Pendamping pengantin: Kisungkeanmi kamara'na kalani pabattumi nikkana, Maknanya: bukalah pintu kamarnya karena kami ingin segera menyatukannya.

Penjaga Kamar: Iyye deng bunting, antama' maki mae. Maknanya: Iya pengantin, masuklah!

Biasanya penjaga kamar dapat uang dari pendamping pengantin laki-laki 50 atau 100 ribu yang disebut dengan istilah doe' somposikali (uang sepupu) ${ }^{13}$, karena pada umumnya pendamping pengantin laki-laki dan penjaga kamar perempuan adalah sepupu dari pengantin.

Saat kedua pengantin baru bertemu untuk pertama kalinya, pengantin lakilaki akan memasangkan cincin kejari manis perempuan (tangan kiri),lalu pengantin perempuan akan mencium tangan suaminya agar sang isteri selalu tunduk patuh kepada suami dan sebagai bentuk penghargaannya kepada suaminya. Kemudian saling bersentuhan jempol tangan kanannya dengan sangat erat, maknanya agar hubungan keduanya selalu erat dan hanya maut yang bisa memisahkan mereka.

Menyentuh telinga isteri agar sang isteri selalu mendengar perkataan suaminya, selagi tidak bertentangan dengan ajaran agama dan harus lemah lembut dalam berkata, berbicara maupun saat menasehatinya. Menyentuh leher makna agar seorang isteri selalu ridho menerima pemberian suaminya, baik dikala lebih maupun berkecukupan. Menyentuh lengan istri agar selalu saling mengingat satu sama lain.

Setelah rangkaian padongko nikkah selesai, maka keduanya akan keluar kamar dan bersanding dipelaminan, inilah yang ditunggu oleh keluarga besar keduanya, kemudian seorang ustazd akan menyampaiakn pesan singkat kepada pengantin baru dan para hadirin yaitu khutbah nikah.

b) Khutbah nikah

Ketika kedua mempelai sudah bersanding di pelaminan maka para hadirin diharap tenang dan khutbah nikah akan berlagsung selama kurang lebih 30 menit. Setelah khutbah nikah selesai, pengantar pengantin laki-laki akan segera pulang dan meminta agar pengantin perempuan segera diantar kemertuanya.

c) Palele (mengantar pengantin perempuan)

Pada umumnya palele dilakukan dipagi hari, setelah melangsungkan akad nikah pada malam harinya. Palele adalah mengantar pengantin perempuan ke rumah suaminya untuk pertama kali setelah menjadi isteri, kedatangannya ini diantar oleh kerabat dekat, tetangga dan masyarakat yang turut diundang. Saat palele orang tua pengantin perempuan, baik ayah maupun ibunya tidak boleh ikut, agar penganting perempuan terbiasa tanpa orangtuanya karena sudah sah menjadi milik suaminya.

Sama halnya saat pasimorong (mengantar pengantin laki-laki), saat palele banyak pula erang-erangnya, seperti: lemari, sarung dan kue tradisional,erang-erang ini disebut pa'matoang. Maksud dari pa'matoang adalah semua erang-erang saat palele akan diganti oleh pihak laki-laki berupa piring, gelas, wajan dan peralatan rumah

\footnotetext{
${ }^{13}$ Kaharuddin, tokoh adat, "Hasil Wawancara”, 09 Desember 2019.
} 
tangga lainnya. Sarung dan kue akan dibagikan oleh orang tua pengantin laki-laki kepada kerabat dan tetangganya yang kemudian akan turut menggantikan dengan peralatan rumah tangga. Namun biasanya erang-erang ini diganti setahun setelah menikah atau setelah pengantin dikaruniai seorang anak.

Semakin banyak erang-erang, semakin banyak pula penggantinya. Tujuan digantikannya erang-erang tersebut supaya anak menantunya tidak direpotkan lagi untuk membeli peralatan rumah tangga jika sudah punya rumah sendiri dan sebagai bentuk kasih sayang seorang ibu kepada anak-anaknya.

d) Mae bisan (pergi kebesan)

Pihak laki-laki berkunjung ke rumah besannya dengan tujuan menemui anak menantunya dan memintanya untuk segera ke rumah suaminya bermalam, yang disebut dengan istilah mae bisan. Orang tua pengantin laki-laki wajib ikut dalam prosesi ini karena tujuannya ingin memanggil anak menantunya. Lain halnya saat pasimorong, orang tua pengantin laki-laki tidak boleh ikut, agar anaknya bisa bertanggung jawab tanpa orang tuanya karena akan menjadi kepala rumah tangga yang penuh tanggungjawab.

Dalam prosesi ini, pihak laki-laki membawa erang-erang, seperi dodol, buras, bannag-bannang dan anaeka macam kue lainnya. Kue ini akan dibagikan oleh orang tua pengantin perempuan kepada kerabat dan tetangga-tetangganya. Kue tersebut akan diganti saat kunjungan balik pihak perempuan kepada mertuanya, yang disebut mae matoang (pergi kemertua).

e) Mae matoang (pergi kemertua)

Mae matoang atau pergi ke rumah mertua adalah kunjungan balik dari pihak perempuan ke pihak pengantin laki-laki, 2-3 hari setelah kedatangan pihak laki-laki ke rumah pengantin perempuan akan dibalas dengan kunjungan balik, kunjungan ini orang tua pengantin perempuan wajib ikut mengantar anaknya ke rumah mertuanya sebagai tanda kerelaan orang tua memberikan hak penuh kepada anak menantunya untuk menjaga anak perempuannya dengan penuh kasih sayang.

Kedatangan orang tua dan keluarga besar pengantin perempuan akan disambut dengan penuh suka-cita oleh pihak pengantin laki-laki, kunjungan ini dibawakan pula erang-erang sama halnya saat kunjungan pihak laki-laki, seperti: dodol, baje, dan kue lainnya. Tujuannya pun sama akan dibagikan oleh orang tua pengantin laki-laki kepada kerabat dan tetangganya.

Prosesi saling mengunjungi satu sama lain akan mempererat hubungan silaturrahim, ini pula yang menjadi salah satu tujuan dari pernikahan, yaitu menjalin hubungan silaturrahmi kepada sesama. Allah berfirman dalam QS. alHujuraat/49: 13.

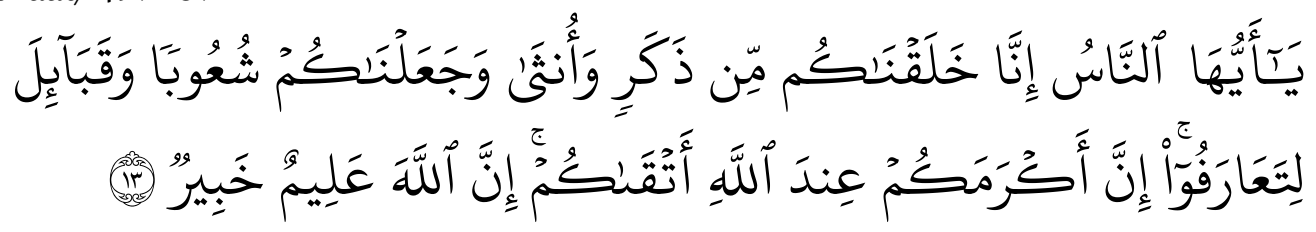

Terjemahnya: 
Wahai manusia! Sungguh, Kami telah menciptakan kamu dari seorang lakilaki dan seorang perempuan, kemudian Kami jadikan kamu berbangsa-bangsa dan bersuku-suku agar kamu saling mengenal. Sungguh, yang paling mulia di antara kamu di sisi Allah ialah orang yang paling bertaqwa. Sungguh, Allah Maha Mengetahui, Mahateliti. ${ }^{14}$

f) Malianngan (mengembalikan)

Maksud dari mengembalikan adalah memberikan beberapa peralatan rumah tangga kepada anak menantunya sebagai pengganti dari erang-erang saat palele. Prosesi ini biasanya dilakukan satu tahun setelah menikah atau setelah keduanya punya keturunan dan digelar dengan cukup meriah karena dihadiri oleh keluarga besar dan tetangga. Inilah akhir dari banyaknya rangkaian dalam adat pernikahan di Kelurahan Cikoro Kecamatan Tompobulu Kabupaten Gowa.

\section{Nilai Budaya Islam dalam Adat Pernikahan di Kelurahan Cikoro.}

1. Memilih jodoh yang tepat, bagi masyarakat di Kelurahan Cikoro sebelum melamar seorang gadis, terlebih dahulu menentukan gadis yang ingin dilamar, setelah ditentukan diutuslah salah satu diplomat untuk mencari informasi tentang gadis tersebut. Dalam buku O. K. Gusi, Yuscan mengatakan: sekalipun jodoh terkadang ditentukan oelh orang tua, namun hak anak tidaklah berarti hak anak dihilangkan sepenuhnya. ${ }^{15}$ Masyarakat di Kelurahan Cikoro, soal pemilihan jodoh lebih ditentukan oleh anak.

2. Melamar. Menurut Dg. Jamaluddin: "Punna nia'mo tau niboya, tena kulle sallo dudu nampa pesta tawwa, jari punna natarima maki nacaritami allo panaikan balanjana siagang pannikkanna, nasaba punna salloi, nikamallakkang ammongkere se're pihak iareka anngaukan takammakamma". ${ }^{16}$ Makna dari pernyataan tersebut, ketika ada seseorang dilamar, pesta dan akad nikahnya dipercepat untuk menghindari fitnah.

3. Silaturrahim, dalam adat pernikahan di Kelurahan Cikoro hubungan silaturrahmi keluarga dan masyarakat luas sangat terlihat erat karena banyaknya rangkaian yang mengundang kerja sama untuk saling membantu satu sama lain.

4. Tolong-menolong, saling menolong sesama sudah menjadi kewajiban sebagai makhluk sosial karena manusia tidak bisa hidup tanpa orang lain. Dalam adat pernikahan di Kelurahan Cikoro saling menolong sudah menjadi kebiasaan sehari-hari, bukan hanya saat hajatan saja.

5. Meninta maaf kepada orang tua, bagi kedua calon pengantin dianjurkan untuk meminta maaf kepada orang tuanya sebelum akad nikah, dan orang tua berhak memberikan maaf dan do'a restu kepada anaknya agar pernikahannya selalu diridhoi oleh Allah swt.

${ }^{14}$ Departemen Agama RI, Alqur'an dan terjemahnya, h. 517,

${ }^{15}$ O. K. Gusti, Pokok-pokok Adat Istiadat Perkawinan Suku Melayu Sumatera Timur (Cet. I; Medan: 2018), h. 20.

${ }^{16}$ Dg. Jamaluddin, tokoh masyarakat, "Hasil Wawancara", 10 Desember 2019. 
6. Berbagi, masyarakat di Kelurahan Cikoro sudah menjadi kebiasaan dalam adat pernikahan untuk berbagi kepada sesama, seperti membagikan sebagian erang-erang pengantin. Selain itu orang tua kedua pengantin setelah selesai acara pernikahan akan disibukkan dengan berbagi kepada kerabat dan tetangganya berupa uang, beras, sarung, gula dan makanan. Ini dilakukan bagi orang tua pengantin sebagai tanda terima kasih atas partisipasinya dalam hajatan yang digelarnya. Anjuran berbagi diajarkan pula dalam Islam sebagaimana Allah berfirman dalam QS. Saba/34: 39.

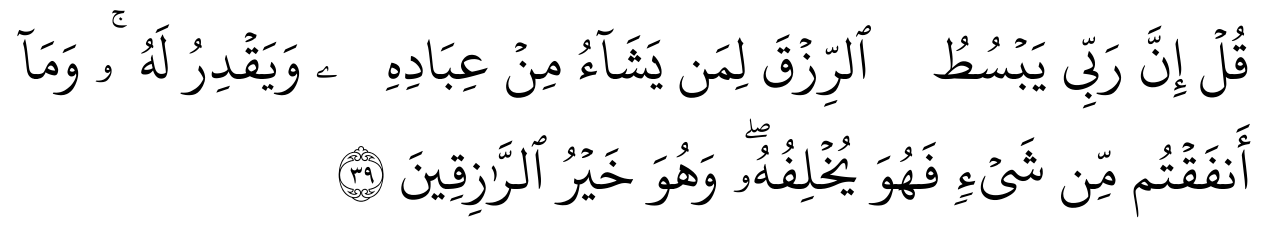

Terjemahnya:

Lapangkan rezeki bagi siapa yang dikehendaki-Nya di antara hamba-hambaNya dan menyempitkan bagi siapa yang dikehendaki-Nya. Dan apa saja yang kamu nafkahkan, Maka Allah akan menggantinya dan Dialah pemberi rezeki yang sebaik-baiknya. ${ }^{17}$

7. Musyawarah adalah salah-satu anjuran dalam Islam untuk memutuskan sebuah perkara, adat pernikahan di Kelurahan Cikoro tidak hanya melibatkan keluarga inti dan tetangga, tetapi masyarakat luas, oleh karenanya setiap perkara harus mengambil jalan musyawarah untuk menhindari kesalahpahaman diberbagai pihak. Allah berfirman dalam QS. Ali-Imran/03: 159.

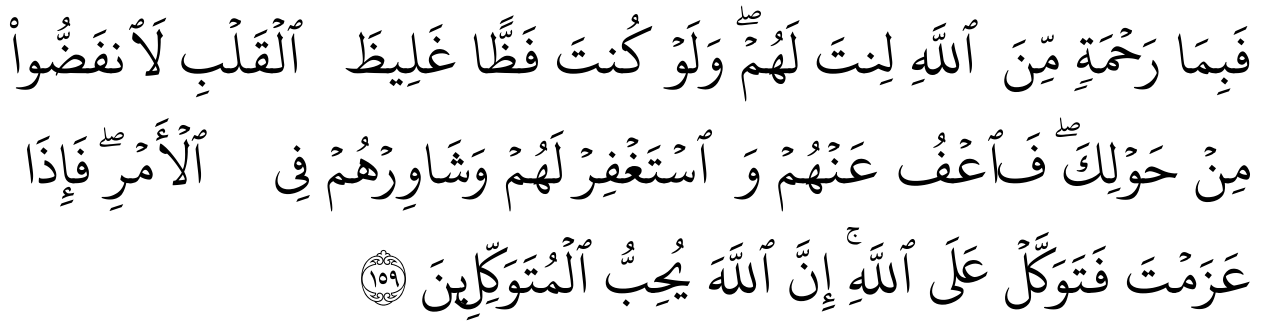

Terjemahnya:

Maka karena rahmat dari Allah-lah kamu berlaku lemah lembut terhadap mereka, sekiranya kamu bersikap keras lagi berhati kasar, tentulah mereka menjauhkan diri dari sekelilingmu, karena itu maafkanlah mereka, mohonkanlahampunan bagi mereka, dan bermusyawaralah dengan mereka dalam urusan itu. Kemudian apabila kamu telah membulatkan tekad, maka bertawakklah kepada Allah, sesungguhnya Allah menyukai orang-orang yang bertawakkal kepada-Nya. ${ }^{18}$

\footnotetext{
${ }^{17}$ Departemen Agama RI, Alqur'an dan Terjemahnya, h. 432.

${ }^{18}$ Departemen Agama RI, Alqur'an dan Terjemahnya, h. 71.
} 
8. Ijab qabul atau akad nikah, masyarakat di Kelurahan Cikoro 100\% beragama Islam, dalam prosesi ijab qabul dilakukan dengan cara islami dan memenuhi semua syarat dan rukun yang telah diatur dalam agama Islam.

Proses Akulturasi Budaya Islam pada Adat Pernikahan di kelurahan Cikoro Kecaman Tompobulu Kabupaten Gowa

Masuknya Islam di Kabupaten Gowa pada tahun $1605 \mathrm{M}$ yang dibawa oleh Datuk Ri Bandang telah membawa pengaruh yang cukup besar bagi masyarakat. Islamisasi telah membawa warna yang baru dan melebur ke dalam warna yang sudah ada, islamisasi dalam pengertian proses sosial budaya yaitu perubahan yang terjadi secara adaptasi atau penyusuaian secarabertahap dari budaya pra Islam kebudaya Islam. ${ }^{19}$

Pertemuan dua budaya atau lebih yang saling menerima satu sama lain atau disebut akulturasi memungkinkan terjadinya ketegangan, tetapi akulturasi di Kelurahan Cikoro justru saling menguntungkan. Akulturasi budaya Islam dengan buday lokal bisa dilihat dalam adat pernikahan di Kelurahan Cikoro.

Pernikahan yang ideal sebelum masuknya Islam adalah pernikahan yang memandang strata sosial, laki-laki dilarang menikahi perempuan yang lebih tinggi stratanya dan hanya boleh menikah dengan orang yang sama stratanya atau lebih rendah.

Sedangkan pernikahan yang ideal setelah masuknya Islam adalah pernikahan sepupu satukali (somposikali) dan sepupu duakali (pindu). Pernikahan sepupu ini sering terjadi karena perjodohan yang dilakukan orang tuanya. Perjodohan di Kelurahan Cikoro sering terjadi karena ingin menyambung kembali keluarga yang jauh untuk menjadi dekat. Terutama pernikahan sepupu duakali (pindu) bagi masyarakat di Kelurahan Cikoro dianggap sebagai hubungan paling baik (passialleang baji).

Namun dalam konteks saat ini menurut hasil penelitian, jika terjadi pernikahan sepupu, bukan lagi karena dijodohkan oleh orang tuanya tetapi keduanya memang saling suka (pacaran). Akulturasi dalam adat pernikahan di Kelurahan Cikoro bisa pula dilihat dari prosesinya, seperti: musyawarah, tolongmenolong, meminta maaf kepada orang tua, semua ini sudah ada sebelum masuknya Islam kemudian menjadi semakin kokoh setelah masuknya Islam.

Itulah sebabnya budaya Islam mudah diterima bagi masyarakat di Kelurahan Cikoro karena ajarannya banyak yang sejalan dengan budaya lokal. Islam tidak serta merta menghilangkan budaya lokal tetapi memberinya nilai-nilai islami, sementara masyarakat pun serta merta meninggalkan budaya yang bertentangan dengan ajaran Islam dan tetap mempertahankan budaya yang sejalan dengan ajaran Islam.

Menurut H. Mahmuddin ${ }^{20}$ pengantin baru bagi masyarakat di kelurahan Cikoro dianjurkan untuk ke pasar membeli tampi dan timba (pa'dingin dan se'ro')

\footnotetext{
${ }^{19}$ M. Ahmad Sewang, Islamisasi Kerajaan Gowa: Abad XVI-XVII (Cet. II; Jakarta: Yayasan Obor Indonesia, 2005), h. 46-47.

${ }^{20}$ H.Mahmuddin, Kepala Lingkungan, “Hasil Wawancara”, 06 Desember 2019.
} 
tujuan dari adat ini agar keduanya menghadapi masalah dengan kepala dingin (tidak emosional) dan rezekinya selalu dilancarkan sepertiorang menimba air.

Selain daripada itu setelah keduanya resmi menjadi suami isteri, orang tua dari pengantin akan mengundang kerabat dan tetangganya secara lisan untuk pengajian (syukuran).

\section{Penutup}

Pernikahan di Kelurahan Cikoro disebut dengan istilah pa'buntingan yang terdiri dari dua tahap, yakni: 1) tahap sebelum pernikahan yang diawali dengan mencari informasi (akkuta'kuta'nang) dan diakhiri dengan akad nikah. 2) tahap setelah pernikahan yang diawali dengan mengantar pengantin perempuan ke rumah mertuanya (palele) dan diakhiri dengan mengembalikan (malianngang) Dalam prosesinya lebih mendahulukan pesta pernikahan daripada akad nikah, pesta digelar dipagi hari pukul 08:00-17:00 dan akad nikah pada malam hari pukul 20:00-selesai.

Adat pernikahan di Kelurahan Cikoro Kecamatan Tompobulu Kabupaten Gowa mengandung banyak nilai-nilai budaya Islam, seperti: memilih jodoh, lamaran, silaturrahim, tolong-menolong, meminta maaf, berbagi,musyawarah dan ijab qabul.

Akulturasi budaya Islam dan budaya lokal dalam adat pernikahan di Kelurahan Cikoro bisa dilihat dalam prosesinya, pengantin baru dianjurkan dalam adat setempat untuk ke pasar membeli tampi dan timba, dalam istilahnya di Kelurahan Cikoro pa'dingin dan se'ro', dengan harapan keduanya menghadapi masalah dengan kepala dingin dan rezekinya dilancarkan seperti orang yang menimba air. Selain itu setelah keduanya resmi menjadi pasangan suami isteri orang tua dari pengantin tersebut akan mengundang kerabat dan tetangganya secara lisan untuk pengajian atau syukuran.

\section{Kesimpulan}

Pa'buntingan atau secara harfiah disebut pernikahan di Kelurahan Cikoro merupakan suatu proses atau kegiatan yang meliputi perencanaan dan pelaksanaan. Tahap persiapan sebelum pernikahan dilakukan seperti musyawarah kemudian tahap pelaksanaan atau hari pernikahan dan tahap setelah pernikahan.

\section{DAFTAR PUSTAKA}

Dahlan, M. "Islam dan Budaya Lokal: Adat Perkawinan Bugis Sinjai". Diskursus Islam 1, no 1 (2013): h. 20-35.

Departemen Agama RI. Alqur'an dan Terjemahnya. Depok: Cahaya Qur'an, 2008.

Hadikusuma, Hilman. Pernikahan Adat. Jakarta: Palapa, 1990.

Junaid, Hamzah. "Kajian Kritis Akulturasi dan Budaya Lokal". Diskursus Islam 1, no 1 (2013): h. 56-73.

Latif, Syarifuddin. Fikih Perkawinan Bugis Tellumpoccoe. Jakarta: Gaung Persada Press, 2017. 
Mone, Abdul Malik. Akkorongtigi dalam Adat dan Upacara Perkawinan Suku Makassar. Makassar, 2009.

Pabittei, St. Aminah. Adat dan Upacara Perkawinan Daerah Sulawesi-Selatan. Cet. IV; Makassar: Dinas Kebudayaan dan Kepariwisataan Prov. Sul-Sel, 2011.

Salihima , Syamsuez. "Islam dan Budaya Lokal di Makassar (Akulturasi dan Agama)". Disertasi. Makassar: PPs UIN Alauddin, 2015.

Sewang, Ahmad M., Islamisasi Kerajaan Gowa: Abad XVI-XVII. Cet. II; Jakarta: Yayasan Obor Indonesia, 2005.

Sumpena, Deden. "Islam dan Budaya Lokal: Kajian terhadap Interaksi Islam dan Budaya Sunda”. Academic Journal for Homiletic Studies 6, no I (2012): h. 102. 120.

Syukur, Syamzan. Arbianti. "Endogami Marriage Tradition Of Sayyid Community In Sidenre Village, Binamu District, Jeneponto Regency”. Adabiyah 19, no I (2019): h. 86-102.

Yunus, Abd. Rahim. "Nilai-nilai Islam dalam Budaya dan Kearifan Lokal". Jurnal Rihlah 2, no 1 (2015): h. 1-12.

Yunus. "Islam dan Budaya: Nilai-nilai Islam dalam Proses Pernikahan Masyarakat Bugis". Jurnal Ilmu Humaniora 2, no 1 (2018): h. 85-99. 